\title{
HASIL TANGKAPAN MINI TRAWL UDANG PADA BERBAGAI PANJANG WARP DAN LAMA TARIKAN
}

\author{
Andria Ansri Utama dan Wudianto \\ Peneliti pada Pusat Riset Perikanan Tangkap, Ancol-Jakarta \\ Teregistrasi I tanggal: 20 April 2009; Diterima setelah perbaikan tanggal: 28 Mei 2009; \\ Disetujui terbit tanggal: 3 Juli 2009
}

\begin{abstract}
ABSTRAK
Mini trawl merupakan alat tangkap hasil modifikasi dari jaring trawl, spesifikasinya dirancang menjadi lebih kecil dari konstruksi umum trawl. Penentuan panjang warp dan lama tarikan pada mini trawl didasarkan pada hasil perkiraan nelayan tanpa perhitungan sebelumnya sehingga kurang efisien. Efisiensi maksimum alat tangkap trawl dipengaruhi beberapa faktor utama, seperti panjang warp, panjang sweepline, kecepatan tarikan, bobot dari footrope, dan lama tarikan. Tujuan penelitian ini untuk mempelajari pengaruh penggunaan perlakuan panjang warp dan perlakuan lama tarikan yang berbeda terhadap hasil tangkapan udang Penaeid pada alat tangkap mini trawl. Penelitian menggunakan metode eksperimen dengan rancangan acak kelompok faktorial yang dilaksanakan pada bulan Maret-April 2007 di perairan Lamongan, Jawa Timur. Hasil penelitian menunjukkan bahwa perlakuan panjang warp berpengaruh nyata terhadap hasil tangkapan udang dengan hasil uji F diterima pada taraf uji $5 \%$. Perlakuan lama waktu penarikkan berpengaruh sangat nyata terhadap hasil tangkapan udang, dengan hasil uji F diterima pada taraf uji 5 dan 1\%. Hasil Tangkapan terbanyak diperoleh dari perlakuan panjang warp $60 \mathrm{~m}$ dengan lama penarikkan 120 menit, bila warp $120 \mathrm{~m}$ hasil tangkapan mengalami penurunan pada lama tarikan 120 menit.
\end{abstract}

\section{KATAKUNCl: $\quad$ mini trawl, warp, towing, udang Penaeid}

\section{PENDAHULUAN}

Sejak tahun 1969 armada penangkapan traw/telah banyak digunakan untuk menangkap udang secara komersial di Indonesia dan mulai berkembang pesat pada tahun 1970-an. Melalui Keppres No.39 tahun 1980 , pemerintah telah melarang pengoperasian jaring trawl sehingga banyak nelayan memodifikasi jaring traw/ menjadi lebih kecil atau dikenal dengan nama mini trawl (Anonimus, 2006).

Jaring trawl berbentuk kantong dan pengoperasiannya dengan cara ditarik (towing) oleh sebuah kapal bermotor dengan menggunakan alat pembuka mulut jaring yang disebut gawang (beam) atau sepasang papan pembuka (otterboard), dapat pula ditarik oleh dua buah kapal bermotor. Pada umumnya jaring trawl terdiri atas sayap, badan, kantong, dan sisi jaring, ditarik horisontal di dalam air sehingga tahanan dari air menyebabkan mulut jaring terbuka. Dalam mulut jaring yang dibatasi oleh tali ris atas dan bawah ini, ikan-ikan dan makhluk lain yang menjadi tujuan penangkapan dapat masuk bersama air yang tersaring (Suhariyanto \& Purnomo, 2005).

Panjang warp dan lama tarikan menjadi faktor penting dalam menentukan keberhasilan pengoperasian jaring trawl (Fridman, 1986). Penggunaan panjang warp yang disesuaikan dengan kondisi kedalaman perairan menentukan posisi jaring yang paling ideal, tidak terlalu mengeruk dasar perairan sehingga lebih meminimalisir dampak kerusakan dasar perairan, tetapi alat tidak melayanglayang jauh di atas dasar perairan berdampak meningkatkan hasil tangkapan sampingan selain udang (Garner, 1988).

Penelitian ini ditujukan untuk mempelajari pengaruh dari panjang warp dan lama tarikan pada mini traw/ terhadap hasil tangkapan udang Penaeid, sehingga dapat diketahui rentangan panjang warpyang paling efisien dioperasikan di perairan Lamongan, Jawa Timur. Nelayan lokal pada umumnya menggunakan panjang warpyang berbeda tergantung pada daerah pengoperasiannya. Selain itu penentuan lama proses tarikan (towing) juga hanya didasarkan pada hasil perkiraan nelayan semata tanpa mengetahui berapa lama tarikan yang paling tepat sehingga pengoperasian alat menjadi efektif dan efisien.

\section{BAHAN DAN METODE}

Penelitian dilakukan dengan mengikuti kegiatan penangkapan 2 unit kapal mini trawl milik nelayan pada bulan Maret-April 2007 di perairan Lamongan, Jawa Timur (Gambar 1). Alat tangkap mini trawl dioperasikan dengan menggunakan panjang warp yang berbeda yaitu 60 dan $120 \mathrm{~m}$ dengan lama tarikkan yang berbeda yaitu 60, 90, dan 120 menit. Pengamatan hasil tangkapan untuk masing-masing unit kapal dilakukan 4 kali ulangan. 


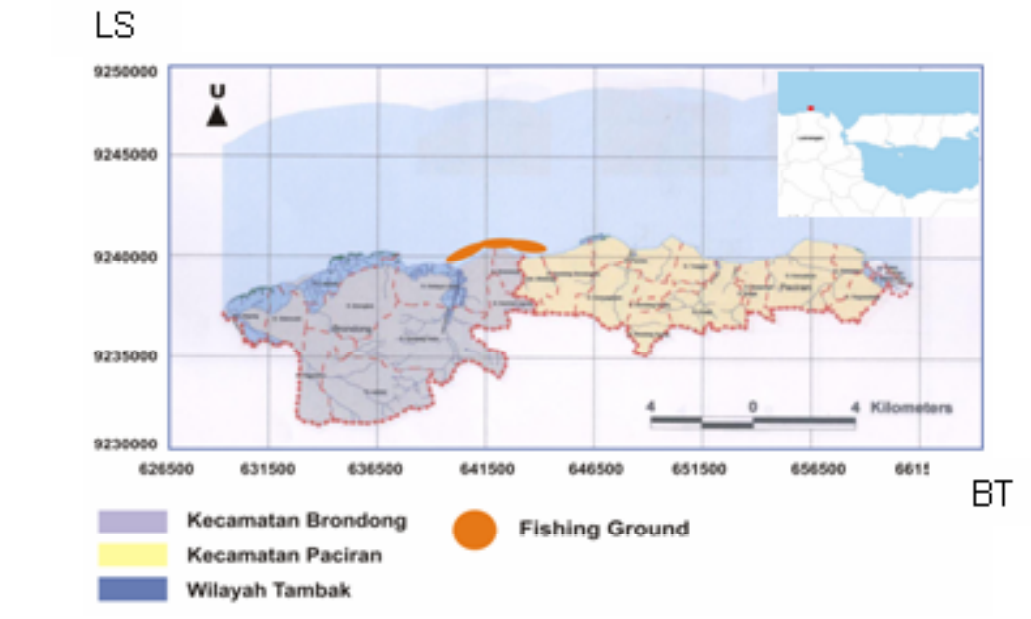

Gambar 1. Peta lokasi daerah penangkapan uji coba mini trawl.

Jaring mini trawl yang dioperasikan memiliki konstruksi terbagi menjadi 4 bagian, yaitu kantong (cod end), badan jaring yang terbagi menjadi 2 bagian yaitu square dan bellies, mulut jaring (panel atas dan bawah) dan sayap. Untuk membuka mulut jaring digunakan sepasang papan rentang (otter board) yang dilengkapi pelampung dan pemberat. Pada otter board dipasangkan tali selambar (warp) yang berfungsi sebagai tali penarik jaring. Ukuran panjang sayap, mulut, badan, dan kantong jaring masing-masing 7 , 1,5, dan $1 \mathrm{~m}$. Bahan jaring terbuat dari poly ethylene dengan ukuran mata jaring untuk setiap bagian yaitu $35 \mathrm{~mm}$ (Gambar 2). Otter board berbahan kayu berbentuk segiempat dengan panjang, lebar dan tebal masing-masing 50, 35, dan $25 \mathrm{~cm}$. Kapal yang digunakan untuk menghela jaring berjenis outer boat berukuran (panjang $\mathrm{x}$ lebar $\mathrm{x}$ dalam) $7,5 \times 2 \times 1,5 \mathrm{~m}$ dilengkapi 2 buah mesin yaitu Dong Feng model $\mathrm{S}$ 1.100 A tipe 4 tak dengan daya 30 dan 23 PK.

Uji coba terdiri atas 6 jenis perlakuan dalam 4 kelompok. Kapal 1 dengan panjang warp $60 \mathrm{~m}$ dilakukan proses lama tarikkan 60, 90, dan 120 menit dan kapal 2 dengan panjang warp $120 \mathrm{~m}$ dilakukan proses lama tarikan 60, 90, dan 120 menit. Keseluruhan pengoperasian berjumlah 24 kali dan hasil tangkapan udang yang masuk ke dalam cod end diidentifikasi, ditimbang kemudian dianalisis dengan model rancangan acak kelompok faktorial. Rancangan acak kelompok digunakan karena percobaan yang akan dilakukan bersifat field experiment, yang pada umumnya sulit untuk mendapatkan kondisi yang benar-benar homogen (Gasperz, 1991).

\section{HASIL DAN BAHASAN}

Udang Penaeid merupakan tujuan utama penangkapan dengan jaring mini trawl, namun dari data hasil tangkapan diperoleh beberapa hasil tangkapan sampingan (bycatch) seperti disajikan pada Tabel 1. Sementara hasil tangkapan utama terdiri atas 3 jenis udang Penaeid, yaitu udang putih (Penaeus merguiensis), udang krosok (Penaeus semiculcatus), dan udang windu (Penaeus monodon) seperti terlihat pada Gambar 3.

Data hasil tangkapan udang dalam satuan bobot $(\mathrm{kg})$ dianalisis menggunakan analisis sidik ragam (uji F) dan diteruskan dengan uji lanjutan uji least significant difference, berdasarkan pada hasil perhitungan diperoleh perlakuan perbedaan panjang warp memberikan hasil yang berbeda nyata, perlakuan perbedaan lama tarikan memberikan hasil yang berbeda sangat nyata dan interaksi antara kedua perlakuan yang dicobakan memberikan hasil yang berbeda nyata.

Berdasarkan pada data Tabel 2 terlihat bahwa hasil tangkapan udang pada interaksi perlakuan panjang warp $60 \mathrm{~m}$ dengan lama tarikkan 60 menit yaitu 1,17 $\mathrm{kg}$, kemudian pada interaksi perlakuan panjang warp $60 \mathrm{~m}$ dengan lama tarikkan 90 menit yaitu $1,46 \mathrm{~kg}$, dan interaksi perlakuan panjang warp $60 \mathrm{~m}$ dengan lama tarikan 120 menit yaitu $3,67 \mathrm{~kg}$. Interaksi penggunaan panjang warp $60 \mathrm{~m}$ dengan tiga pola lama waktu penarikan 60, 90, dan 120 menit menunjukkan hasil semakin lama proses penarikkan dilakukan akan semakin banyak hasil tangkapan. Pada panjang warp $120 \mathrm{~m}$ dengan lama tarikkan 60 menit diperoleh hasil tangkapan udang $0,53 \mathrm{~kg}$, kemudian pada interaksi perlakuan panjang warp $120 \mathrm{~m}$ dengan lama waktu penarikan 90 menit yaitu $1,97 \mathrm{~kg}$, dan interaksi perlakuan panjang warp $120 \mathrm{~m}$ dengan lama waktu penarikan 120 menit yaitu $1,94 \mathrm{~kg}$. Hasil tangkapan terus meningkat sampai lama tarikan 90 menit, setelah lama tarikan 120 menit hasil tangkapan mengalami penurunan. Jumlah hasil tangkapan udang 


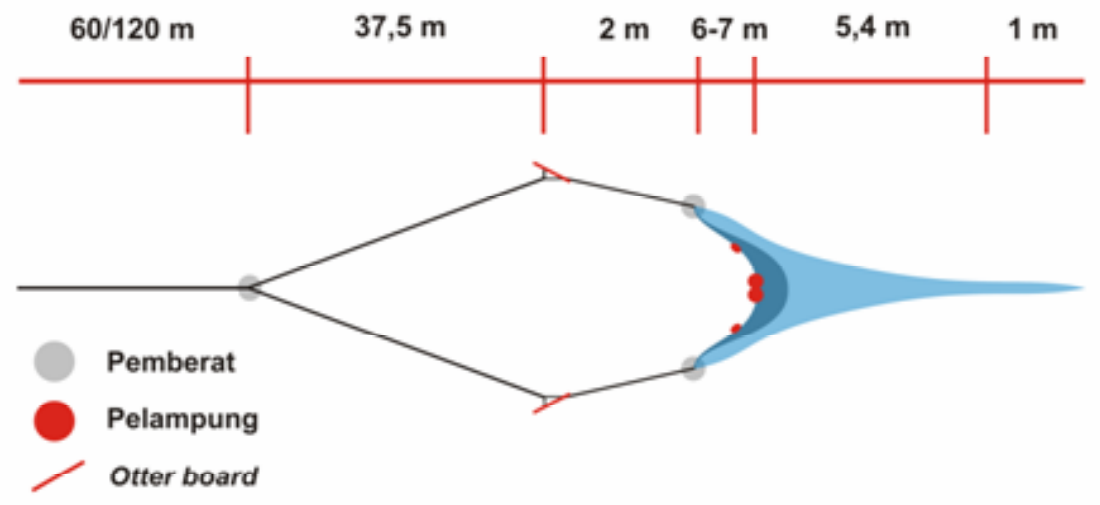

Gambar 2. Keragaan dan ukuran alat tangkap mini trawl.

Tabel 1. Komposisi hasil tangkapan sampingan dari mini trawl

\begin{tabular}{clcc}
\hline No. & \multicolumn{1}{c}{ Jenis } & Jumlah (ekor) & Persentase (\%) \\
\hline 1. & Tenggiri (Scomberomorus spp.) & 1 & $0,02 \%$ \\
2. & Belanak (Mugil spp.) & 205 & $4,87 \%$ \\
3. & Keting (Arius nela) & 71 & $1,69 \%$ \\
4. & Selar (Selar spp.) & 85 & $2,02 \%$ \\
5. & Kapas (Gerres spp.) & 198 & $4,70 \%$ \\
6. & Lidah dan Sebelah (Psettodidae) & 281 & $6,68 \%$ \\
7. & Sotong (Sephia spp.) & 9 & $0,21 \%$ \\
8. & Cumi (Loligo spp.) & 2.405 & $57,14 \%$ \\
\hline
\end{tabular}

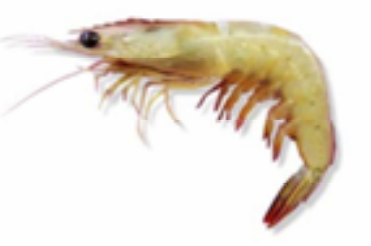

Udang putih

(Penaeus merguiensis)

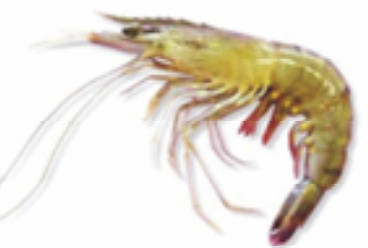

Udang windu

(Penaeus

monodon)

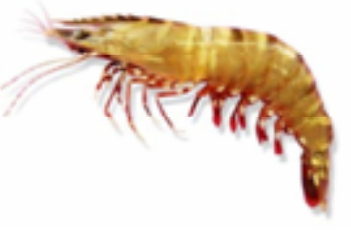

Udang krosok

(Penaeus

semisulcatus)

Gambar 3. Jenis udang Penaeid yang tertangkap.

Tabel 2.

Hasil tangkapan udang Penaeid dalam jaring mini trawl

\begin{tabular}{|c|c|c|c|c|c|c|c|}
\hline \multirow{2}{*}{$\begin{array}{c}\text { Perlakuan panjang } \\
\text { warp }\end{array}$} & \multirow{2}{*}{ Perlakuan lama tarikan } & \multicolumn{4}{|c|}{ Ulangan/Replication } & \multirow{2}{*}{$\begin{array}{c}\text { Jumlah } \\
(\mathrm{kg})\end{array}$} & \multirow{2}{*}{ Rata-rata } \\
\hline & & 1 & 2 & 3 & 4 & & \\
\hline \multirow[t]{3}{*}{ Warp I (60 m) } & Tarikan I (60 menit) & 0,31 & 0,12 & 0,40 & 0,34 & 1,17 & 0,29 \\
\hline & Tarikan II (90 menit) & 0,50 & 0,25 & 0,51 & 0,20 & 1,46 & 0,36 \\
\hline & Tarikan III (120 menit) & 0,61 & 1,20 & 1,03 & 0,83 & 3,67 & 0,91 \\
\hline \multirow{3}{*}{ Warp /I (120 m) } & Tarikan I (60 menit) & 0,12 & 0,10 & 0,20 & 0,11 & 0,53 & 0,13 \\
\hline & Tarikan II (90 menit) & 0,50 & 0,35 & 0,52 & 0,60 & 1,97 & 0,49 \\
\hline & Tarikan III (120 menit) & 0,11 & 0,59 & 0,78 & 0,46 & 1,94 & 0,48 \\
\hline Jumlah & & 2,15 & 2,61 & 3,44 & 2,54 & 10,74 & \\
\hline
\end{tabular}

berdasarkan pada tiap jenis perlakuan yang dicobakan yaitu panjang warp dan lama tarikan dapat dilihat pada Gambar 4.

Gambar 5 menjelaskan interaksi perlakuan panjang warp 60 m dengan lama tarikan 120 menit memberikan hasil tangkapan udang yang terbaik sementara interaksi perlakuan panjang warp $120 \mathrm{~m}$ dengan lama tarikkan 60 menit memberikan hasil tangkapan udang paling sedikit. Pada Gambar 5 juga terlihat terjadinya penurunan hasil tangkapan udang bila menggunakan panjang warp $120 \mathrm{~m}$ dengan lama tarikkan 120 menit. 
Apabila proses penarikan 90 menit penggunaan panjang warp $120 \mathrm{~m}$ memberikan hasil tangkapan udang yang lebih besar dibandingkan panjang warp $60 \mathrm{~m}$.

Perlakuan panjang warp dengan ukuran $60 \mathrm{~m}$ memberikan hasil tangkapan udang yang paling baik dibandingkan dengan menggunakan warp dengan ukuran $120 \mathrm{~m}$ karena posisi jaring tepat berada pada dasar perairan dan tidak terlalu dalam mengeruk dasar atau melayang-layang di atas dasar sehingga dengan lama tarikkan sampai 120 menit menunjukkan hasil tangkapan udang yang semakin meningkat, hal ini menunjukkan gaya bobot yang diterima oleh jaring dari bertambahnya volume tangkapan dan tahanan aliran air laut yang melewati jaring tidak berpengaruh terhadap bukaan maksimal mulut jaring. Kondisinya berbeda dengan perlakuan panjang warp $120 \mathrm{~m}$, hasil tangkapan udang mengalami peningkatan hanya sampai lama tarikkan 90 menit sementara pada lama tarikkan 120 menit hasil tangkapan udang mengalami penurunan. Pada lama tarikan 90 menit gaya bobot dan tahanan yang diterima oleh jaring dari bertambahnya volume tangkapan dan aliran air laut yang melewati jaring belum mempengaruhi bukaan maksimal mulut jaring, sementara pada lama tarikkan 120 menit mulut jaring tidak dapat terbuka secara optimal disebabkan pengaruh bertambahnya gaya bobot dan tahanan dari volume hasil tangkapan yang bertambah dan aliran air laut yang melewati jaring. Menurut Garner (1988), pada saat proses penarikkan, efektivitas alat tangkap dipengaruhi oleh beberapa gaya seperti gaya tarik dari perahu, gaya tahanan dari air laut, gaya dari tekanan air menuju tali warp, gaya bukaan papan rentang, perubahan gaya bobot dari hasil tangkapan yang berubah-ubah, dan pembatasan aliran air laut yang melewati jaring. Berdasarkan pada pengamatan, ditemukan jauh lebih banyak bongkahan karang mati, batu besar dan sampah-sampah plastik, maupun non plastik di dalam jaring pada penggunaan warp $120 \mathrm{~m}$ dibandingkan 60 $m$ yang berakibat jauh lebih besarnya gaya bobot dan tahanan yang diterima jaring saat ditarik.

Warp dengan panjang $120 \mathrm{~m}$ terlalu panjang bila digunakan karena kedalaman perairan tempat operasi penangkapan berkisar antara 18-22 m, sementara warp $60 \mathrm{~m}$ paling sesuai dengan kedalaman perairan. Menurut Sudirman \& Mallawa (2004), pada umumnya panjang warp sekitar 3-4 kali kedalaman perairan, sementara perbandingan 6-7 kali pada daerah penangkapan dengan kedalaman sekitar $9 \mathrm{~m}$. Garner (1988), mengatakan bahwa secara teori perbandingan panjang warp dengan kedalaman perairan yang ideal adalah 3:1, bila warp yang digunakan ukurannya tidak sesuai (over length) dengan kedalaman daerah penangkapan, jaring akan mengeruk dasar perairan ketika proses penarikan berlangsung, tetapi sebaliknya jaring melayang-layang tidak dapat mencapai dasar perairan jika panjang warp terlalu pendek. Sementara menurut Fujimori et al. (2005), perbandingan warp dengan kedalaman perairan 3:1 dan 3:5 memberikan hasil tangkapan lebih banyak dibandingkan 2:5. Pada perbandingan 2:5 jaring diperkirakan tidak dapat mencapai dasar. Dengan kondisi dasar perairan tempat operasi penangkapan yang berlumpur, untuk mencegah jaring mengeruk lumpur lebih baik jika warp diperpendek dan sebaliknya bila kondisi dasar laut pasir keras lebih baik warp diperpanjang (Sudirman \& Mallawa, 2004).
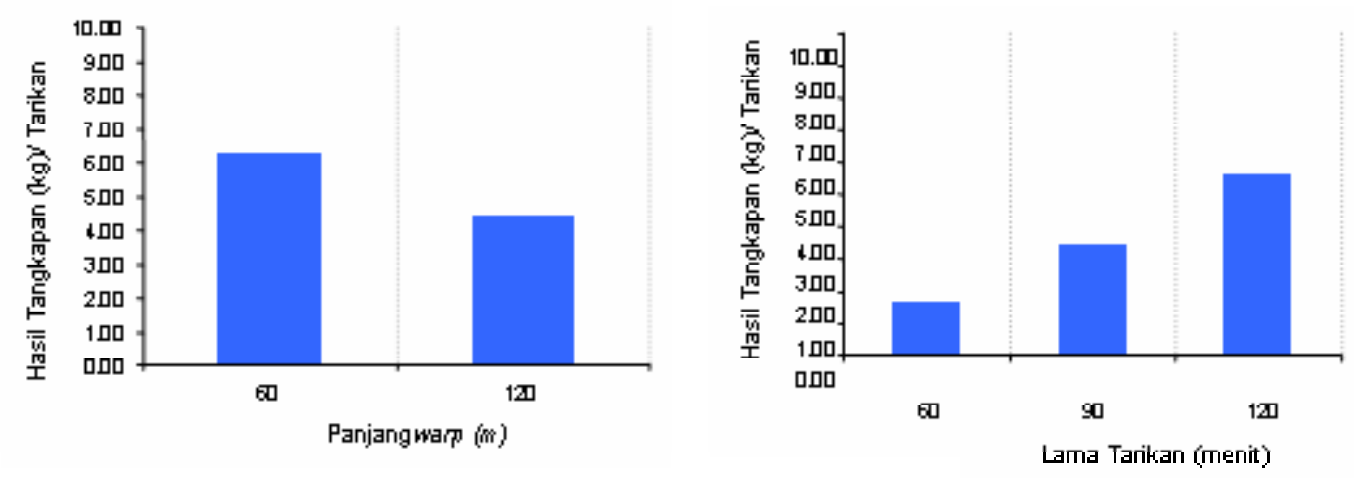

Gambar 4. Histogram tangkapan udang Penaeid dengan perlakuan, (a) dua panjang warp yang berbeda dan (b) perlakuan tiga lama tarikan yang berbeda. 


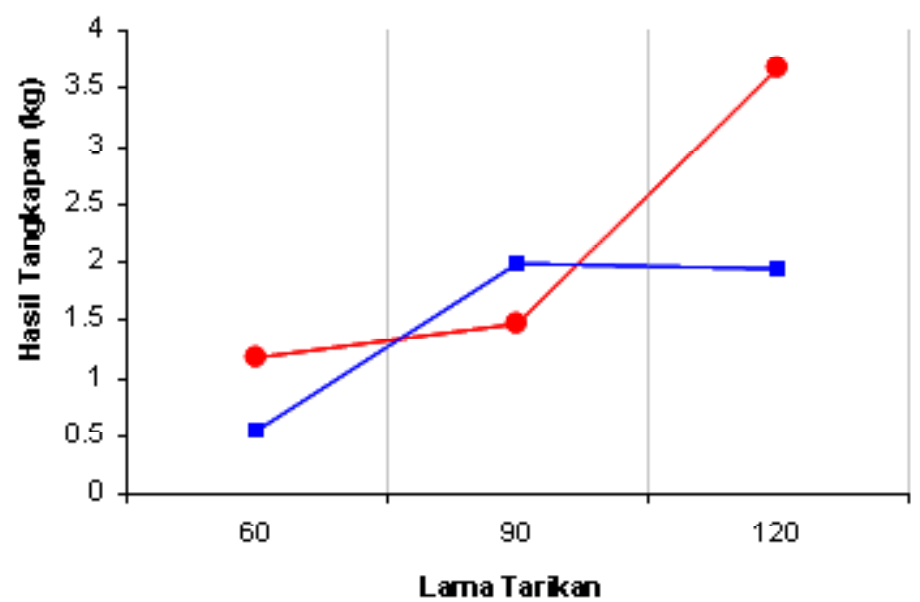

—-Panjang warp $60 \mathrm{~m}-$-Panjang warp $120 \mathrm{~m}$

Gambar 5. Interaksi antara panjang warp dengan lama tarikan pengaruhnya terhadap hasil tangkapan udang.

\section{KESIMPULAN}

1. Perlakuan panjang warp $60 \mathrm{~m}$ memberikan hasil yang lebih banyak dari panjang warp $120 \mathrm{~m}$ dan semakin lama proses penarikan akan memberikan hasil yang lebih banyak pula.

2. Ada interaksi kedua perlakuan, panjang warp 60 $\mathrm{m}$ dengan lama lama tarikan 120 menit memberikan hasil yang terbaik dan pada panjang warp $120 \mathrm{~m}$ paling optimal lama proses tarikan hanya sampai 90 menit, hasil tangkapan mengalami penurunan bila lama tarikan 120 menit.

3. Terdapat tiga spesies udang Penaeid yang tertangkap, udang putih (Penaeus merguiensis), udang windu (Penaeus monodon), dan udang krosok (Penaeus semisulcatus).

\section{PERSANTUNAN}

Tulisan ini merupakan dari hasil riset pengaruh perbedaan panjang warp dan lama waktu penarikan (towing) pada alat tangkap mini traw/ terhadap hasil tangkapan udang di Desa Weru, Kabupaten Lamongan, Jawa Timur, tahun 2007.

\section{DAFTAR PUSTAKA}

Anonimus. 2006. Identifikasi Beberapa Alat Penangkapan Ikan yang Diperbolehkan dan yang Dilarang oleh Pemerintah Indonesia. www.dkp.go.id/content.php?c=2590. Diunduh tanggal 11 Oktober 2006.

Fridman. 1986. Calculations for fishing gear designs. Food and Agriculture Organization of United Nations. Roma. 301 pp.

Fujimori, Y., K. Chiba, T. Oshima, K. Miyashita, \& S. Honda. 2005. The influence of warp length on trawl dimension and catch of walleye pollock theragra chalcogramma in a bottom trawl survey. The Japanese Society of Fisheries Sciences. Hokkaido.18pp.

Garner, J. 1988. Modern Deep Sea Trawling Gear. Harlnolls Limited. Bodmin. Cornwall. London. 96 pp.

Gasperz, V. 1991. Metode Perancangan Percobaan. Armico. Bandung. $471 \mathrm{pp}$.

Sudirman \& A. Mallawa. 2004. Teknik penangkapan Ikan. Rineka Cipta. Jakarta. 164 pp.

Suhariyanto \& A. Purnomo. 2005. Petunjuk Teknis Identifikasi Sarana Perikanan Tangkap Pukat Tarik (Trawl). Balai Pengembangan Penangkapan Ikan Semarang. Semarang. 20 pp. 